\title{
ANALISIS KEMAMPUAN METAKOGNISI SISWA DALAM MEMECAHKAN MASALAH MATEMATIS DI SMPN 3 X KOTO SINGGALANG KABUPATEN TANAH DATAR DITINJAU DARI GENDER
}

\author{
Risda Weni ${ }^{1}$, Elda Herlina ${ }^{2}$, Nola Nari $^{3}$ \\ ${ }^{1}$ Jurusan Tadris Matematika Fakultas Tarbiyah dan Ilmu keguruan IAIN Batusangkar \\ 2 IAIN Batusangkar \\ elda.herlina@iainbatusangkar.ac.id \\ ${ }^{3}$ IAIN Batusangkar \\ nolanari@iainbatusangkar.ac.id
}

\begin{abstract}
Abstrak
The lack of students' awareness and comprehension in solving math problems was the research background. The teacher only emphasizes the results and does not evaluate the process of students' cognitive aspects and their awareness in answering the questions. The purpose of this research is to figure out how the metacognition abilities of male and female students solve math problems. The research design was descriptive research. The techniques of data collection were a test for measuring students' metacognition ability in solving math problems, students' worksheet, and interview. Then, it was analyzed through scoring procedures, tabulating data and determining the category of metacognition abilities. Meanwhile, the data from interview were analyzed by conducting several procedures such as reducing data, providing data, and drawing conclusions. The research results showed there were no differences in the metacognition abilities between male and female students.
\end{abstract}

Keywords: Metacognition Ability, Solving procedures of Math Problems, Gender

\section{PENDAHULUAN}

Pada pembelajaran matematika, siswa mengetahui dan memahami strategi apa yang akan digunakannya untuk menyelesaikan masalah matematis. Selain itu, siswa juga perlu mengetahui kelebihan dan kekurangannya strategi penyelesaian masalah yang digunakan. Kesadaran siswa terhadap proses dan hasil pikirnya disebut kemampuan metakognisi (Afriyani, 2011). Metakognisi merupakan pemaknaan berpikir yang dapat diaplikasikan sebagai suatu strategi untuk mengondisikan siswa dalam menyelesaikan masalah, mengambil keputusan, menarik kesimpulan, berpikir kritis dan berpikir kreatif (Martinis Yamin, 2013). Berdasarkan hal yang diungkapkan Martinis Yamin, salah satu pengaplikasian dari metakognisi adalah menyelesaikan masalah. Sejalan dengan hal itu O'Neil \& Brown juga menyatakan bahwa metakognisi sebagai proses dimana seseorang berpikir tentang berpikir dalam rangka membangun strategi untuk memecahkan masalah (Akhsanul In'am, 2011). Jadi, metakognisi sangat penting dimiliki siswa agar memudahkan siswa untuk mengambil strategi yang tepat untuk digunakan saat menyelesaikan suatu masalah. Memecahkan masalah matematis merupakan tujuan pembelajaran untuk memahami dan mengetahui suatu persoalan matematika, sehingga setiap siswa di tuntut mampu memecahkan masalah pembelajaran matematika.

Dalam menyelesaikan masalah matematis tergantung pada setiap individu masing-masing mengenai apa yang telah mereka ketahui dan bagaimana cara mengerjakannya. Berikut ini, indikatorindikator yang digunakan untuk mengukur kemampuan metakognisi siswa dalam 
menyelesaikan masalah matematis (Laily Agustina Mahromah, 2013):

\section{Perencanaan}

Indikator yang digunakan dalam mengukur kemampuan metakognisi pada perencanaan adalah:

a. Kemampuan siswa dalam memahami masalah matematis.

b. Kemampuan siswa dalam merencanakan strategi penyelesaian masalah matematis.

2. Pemantauan

Indikator yang digunakan dalam mengukur kemampuan metakognisi pada pemantauan adalah: kemampuan siswa dalam menyadari hal-hal yang sedang dipantau dalam menyelesaikan masalah matematis.

3. Penilaian

Indikator yang digunakan dalam mengukur kemampuan metakognisi pada penilaian adalah: kemampuan dalam melakukan evaluasi dalam penyelesaian masalah matematis.

Berdasarkan hasil wawancara dengan guru di SMPN 3 X Koto Singgalang Kabupaten Tanah Datar pada tanggal 22 Juli 2017 diketahui bahwa dalam mengevaluasi aspek kognitif siswa, guru hanya menekankan pada hasilnya saja dan belum mengevaluasi aspek proses kognitif. Guru hanya melihat pemahaman siswa berdasarkan hasil yang diperoleh siswa dalam ulangan harian, latihan, tugas, PR ataupun dari cara siswa menjawab pertanyaan selama proses belajar mengajar. Guru tidak mengevaluasi cara siswa untuk mendapatkan jawaban dari persoalan ataupun soal yang diberikan. Contohnya, guru tidak bertanya secara individu kepada siswa perempuan maupun siswa laki-laki bagaimana siswa mendapatkan jawaban tersebut, apa yang dipahami siswa dari persoalan yang diberikan, apa yang dipikirkan siswa ketika melihat persoalan yang dihadapi, apa yang menyebabkan siswa menggunakan strategi tertentu dalam menyelesaikan masalah, apakah siswa yakin dengan strategi yang dipilih, dan pertanyaan-pertanyaan lain yang merangsang pemikiran siswa.

Pemikiran siswa perempuan dan siswa laki-laki dalam menyelesaikan masalah matematika sangat berbeda antara siswa yang satu dengan yang lainnya. Berdasarkan hasil observasi ditemukan bahwa siswa perempuan menyelesaikan masalah matematika sesuai dengan konsep yang diajarkan, sedangkan siswa laki-laki lebih menggunakan strateginya masingmasing tetapi hasilnya benar. Namun ketika ulangan siswa laki-laki lebih banyak menjawab dengan konsep yang singkat dan lebih cepat mengumpulkan jawabannya, berbeda dengan siswa perempuan, dimana menyelesaikan masalah sesuai dengan konsep.

Berdasarkan dari lembar jawaban siswa laki-laki dan siswa perempuan, dapat dilihat siswa memecahkan masalah. Siswa laki-laki dan siswa perempuan mempunyai caranya masing-masing untuk memecahkan masalah ini, namun belum dapat dilihat cara pola pikir dan kesadaran siswa untuk menjawab soal, maka dari itu peneliti ingin menganalisis kemampuan metakognisi siswa laki-laki dan siswa perempuan. Menurut Geary, Sault dan Liu (Gatut Iswahyudi, 2012) bahwa pengaruh faktor gender (pengaruh perbedaan laki-laki dan perempuan) dalam matematika adalah karena adanya perbedaan biologis dalam otak anak laki-laki dan perempuan, bahwa anak perempuan, secara umum, lebih unggul dalam bidang bahasa dan menulis, sedangkan anak laki-laki lebih unggul dalam bidang matematika karena kemampuankemampuan keruangan yang lebih baik. Siswa laki-laki dan perempuan memiliki karakter masing-masing untuk menemukan strategi yang tepat untuk memecahkan masalah, siswa yang memilih kesadaran pola pikir yang baik, maka ia akan mengontrol, merancang, memantau dan menilai apa yang telah dicari sehingga mendapatkan jawabannya yang benar. 
Berpedoman pada permasalahan di SMPN 3 X Koto Singgalang Kabupaten Tanah Datar, maka perlu untuk menganalisis kemampuan metakognisi siswa dalam memecahkan masalah matematis pada siswa kelas VII di SMPN 3 X Koto Singgalang Kabupaten Tanah Datar ditinjau dari gender.

\section{METODE}

Jenis penelitian ini adalah penelitian deskriptif. Penelitian ini dilaksanakan di SMPN 3 X Koto Singgalang Kabupaten Tanah Datar dengan subjek penelitian yang diambil dalam penelitian ini adalah semua siswa kelas VII berjumlah 78 orang siswa.

Prosedur penelitian dibedakan menjadi dua tahap yaitu tahap awal dan tahap inti. Kegiatan yang dilakukan pada tahap awal adalah pengembangan tes, pelaksanaan tes dan pemilian subjek wawancara. Pengembangan tes dilakukan dengan menentukan tujuan diadakan tes dan merumuskan kisi-kisi tes dan menyusun tes kemampuan metakognisi, setelah itu dilakukan validasi tes, yaitunya validasi isi dan validasi muka oleh validator. Setelah soal valid, maka soal tersebut diujicobakan di kelas yang homogen dengan kelas penelitian yaitunya kelas VII. 3. Soal yang telah layak untuk dipakai jika Ip (indeks pembeda) signifikan dan $0 \%<\mathrm{Ik}$ (Indeks kesukaran) $<100 \%$. Soal yang telah layak diberikan kepada subjek penelitian yaitunya kelas VII. Hasil tes siswa dinilai berdasarkan rubrik penilaian dan pedoman pemberian skor.

Tabel 1. Skor Kemampuan Pemecahan Masalah Matematika Siswa

\begin{tabular}{c|l|c}
\hline No & Reaksi Terhadap Masalah & Skor \\
\hline 1 & $\begin{array}{l}\text { Tidak ada jawaban/menjawab tidak sesuai dengan } \\
\text { pertanyaan/tidak ada yang benar. }\end{array}$ & 0 \\
\hline 2 & $\begin{array}{l}\text { Jawaban hampir tidak mirip/sesuai dengan pertanyaan, } \\
\text { persoalan atau dengan masalah. }\end{array}$ & 1 \\
\hline 3 & $\begin{array}{l}\text { Jawaban ada beberapa yang mirip/sesuai dengan } \\
\text { pertanyaan, persoalan atau dengan masalah tapi } \\
\text { hubungannya tidak jelas. }\end{array}$ & 2 \\
\hline 4 & $\begin{array}{l}\text { Jawaban mirip atau sesuai dengan pertanyaan, persoalan } \\
\text { atau dengan masalah tapi kurang lengkap. }\end{array}$ & 3 \\
\hline 5 & $\begin{array}{l}\text { Jawaban mirip atau sesuai dengan pertanyaan, persoalan } \\
\text { atau dengan masalah secara lengkap. }\end{array}$ & 4 \\
\hline
\end{tabular}

Sumber: Modifikasi dari Mirzano 2006

Setelah itu, siswa digolongkan menjadi 3 kategori skor matematika berdasarkan rentang nilai dengan menggunakan standar deviasi berikut: (Ilyas, 2006)

1) Skor tinggi $\geq$ Mean + SD.

2) Mean $-\mathrm{SD}<$ skor sedang < Mean + SD.

3) Skor rendah $\leq$ Mean $-\mathrm{SD}$.

Berdasarkan penggolongan kategori skor tersebut, maka dipilih 3 orang siswa dari masing-masing kategori untuk dijadikan subjek wawancara. Pemilihan subjek wawancara didasarkan pada studi hasil kerja siswa yang mewakili masing- masing kategori yang ada, yaitunya tinggi, sedang dan rendah. Setelah subjek dipilih maka dilaksanakan wawancara dengan tujuan untuk mengetahui kemampuan metakognisi siswa dalam memcahkan masalah matematis. Wawancara dilakukan untuk memperoleh informasi yang lebih mendalam yang tidak dapat terlihat pada hasil kerja siswa. Sebelum wawancara dilaksanakan, maka dilakukan penyusunan pedoman wawancara yang mengacu pada indikator kemampuan metakognisi dalam memecahkan masalah matematis, sehingga wawancara yang dilaksanakan dapat terarah dan dan mencapai tujuan yang diinginkan. 
Kategori predikat kemampuan metakognisi siswa dapat dilihat pada Tabel 2 .

Tabel 2: Predikat Kemampuan Pemecahan Masalah Matematis

\begin{tabular}{l|l}
\hline Kategori & Kriteria \\
\hline $\mathrm{A}=$ Sangat memuaskan & $81 \%-100 \%$ \\
\hline $\mathrm{B}=$ Memuaskan & $61 \%-80 \%$ \\
\hline $\mathrm{C}=$ Cukup memuaskan & $41 \%-60 \%$ \\
\hline $\mathrm{D}=$ Kurang memuaskan & $21 \%-40 \%$ \\
\hline $\mathrm{E}=$ Tidak memuaskan & $0 \%-20 \%$ \\
\hline
\end{tabular}

Teknik analisis data yang digunakan untuk data kuantitatif adalah (1) skoring, yaitu penentuan jumlah skor; (2) tabulasi data, yaitu menyusun data ke dalam tabeltabel yang mudah dibaca yang nantinya digunakan untuk menganalisis data; dan (3) menentukan predikat kemampuan pemecahan masalah matematis pada setiap kategori dengan menggunakan rumus:

Persentase skor rata-rata $=$ $\frac{\text { rara-rara }}{\text { Lskor ideab }} \times 100 \%$.

Setelah ditentukan pesentase skor rata-rata, maka ditentukan prediket kemampuan pemecahan masalah matematis dengan meggunakan skala lima sebagai berikut: (Arikunto, 2005)

Teknik analisis data untuk data kualitatif adalah (1) reduksi data, yaitu merangkum, memilih hal-hal pokok, memfokuskan pada hal-hal penting, dicari tema dan polanya dan membuang yang tidak perlu; (2) penyajian data, yaitu kegiatan menyajikan data dalam bentuk uraian singkat (Sugiyono, 2010) verifikasi, kesimpulan dalam penelitian kualitatif yang diharapkan adalah temuan baru yang sebelumnya belum pernah ada.

\section{PEMBAHASAN}

Hasil Analisis Data Kemampuan Metakognisi Siswa Laki-Laki dalam Memecahkan Masalah Matematis

Data hasil tes yang diperoleh untuk kemampuan metakognisi pada siswa lakilaki:

Tabel 3: Hasil Tes Kemampuan Metakognisi Siswa dalam Memecahkan Masalah Matematis

\begin{tabular}{c|c}
\hline Ukuran & Siswa Laki-Laki \\
\hline Rata-rata & 20,17 \\
\hline Skor Tertinggi & 30 \\
\hline Skor Terendah & 7 \\
\hline Standar Deviasi & 6,12 \\
\hline
\end{tabular}

Berdasarkan tabel di atas diperoleh persentase rata-rata bahwa dari 34 orang siswa laki-laki dari 78 siswa yang mengikuti tes kemampuan metakognisi siswa laki-laki sudah dalam kategori Memuaskan $(63,03 \%)$ dari skor ideal

Berdasarkan hasil kerja siswa dan wawancara diperoleh indikator kemampuan metakognisi:

a. Indikator Perencanaan
Kemampuan metakognisi siswa lakilaki yang baik dalam memecahkan masalah matematis mampu memahami masalah karena dapat mengungkapkannya dengan jelas, siswa tidak mengalami kesulitan dan kebingungan untuk menemukan konsep, dan siswa dapat menjelaskan sebagian besar apa yang ditulisnya. Siswa dapat memahami masalah yang berkaitan dengan belah ketupat, persegi panjang, dan persegi yang peneliti berikan, sehingga siswa dapat 
menjelaskan unsur yang diketahui, unsur yang ditanya dan siswa juga dapat memeriksa kecukupan informasi yang ada pada soal. Sejalan dengan hal tersebut, menurut Wilson (Laily Agustina Mahromah, 2013) menyatakan bahwa menyatakan bahwa kesadaran berpikir seseorang dapat diamati, sehingga tingkat kesadaran berpikir siswa dapat diamati pada langkah-langkah yang dilakukannya dalam menyelesaikan suatu masalah.

\section{b. Indikator Pemantauan}

Kemampuan metakognisi siswa lakilaki pada indikator pemantauan yaitu siswa mampu memberi alasan yang mendukung pemikirannya. Siswa dengan kemampuan metakognisi yang baik dapat memberikan alasan kenapa siswa menggunakan konsep (rumus) tertentu dalam penyelesaian jawabannya.

Siswa mengungkapkan alasan siswa menggunakan rumus luas persegi panjang, persegi, belah ketupat, phytagoras dan keliling. Siswa dapat memberikan alasan kenapa siswa menyajikan masalah ke dalam konsep matematika. Hal tersebut sejalan dengan hasil penelitian dari Kamid (2013) subjek laki-laki menjawab langsung pertanyaan dan tetap melihat pada lembar jawaban peneliti melontarkan pertanyaan pada subjek laki-laki yaitu dengan menggunakan rumus, apakah ada kendala dalam melakukan operasi hitungnya?, subjek menjawab secara langsung yaitu "tidak". Subjek dapat menjawab pertanyaan yang dilontarkan oleh peneliti disini terjadi proses metakognisi dimana subjek dapat melaksanakan rencana tindakan dengan memilih strategi penyelesaian masalah matematika karena subjek tidak mengalami kesulitan dan melakukan langkah-langkah dengan mantap.

c. Indikator Penilaian

Kemampuan metakognisi siswa lakilaki pada indikator penilaian yaitunya, siswa melakukan evaluasi. Evaluasi yang dilakukan setelah menyelesaikan masalah tersebut, yaitu siswa memeriksa setiap langkah yang dibuatnya, konsep (rumus) yang siswa gunakan ataupun cara menghitung yang siswa lakukan. Hal tersebut dapat terlihat pada hasil kerja siswa di lembar jawaban dan pada saat wawancara. Siswa laki-laki yang memiliki kemampuan metakognisi melakukan evaluasi terhadap apa yang dibuatnya, dimana siswa mengecek kembali terhadap semua langkah dan hasil jawaban yang dibuatnya. Hal tersebut didukung oleh penelitian Livingstone (1997) Subjek lakilaki dalam mengecek kembali mengungkapkan jawaban dengan santai sambil terus melihat lembar tugas jawabannya dan sangat yakin dengan jawaban yang ia peroleh. Sehingga subjek laki-laki dalam mengungkapkan jawaban telah mengevaluasi dan meneliti kembali bagaimana penyelesaian terbaik (Kamid, 2013).

Berdasarkan urutan indikator kemampuan metakognisi siswa mulai dari perencanaan, pemantauan dan penilaian, maka siswa yang memiliki kemampuan metakognisi baik siswa dapat menjelaskan apa yang diketahui dari masalah, menunjukan adanya kesadaran terhadap apa saja yang dipantau, dan melakukan evaluasi. Kemampuan metakognisi yang cukup baik, dalam merencanakandan mengevaluasi yang baik, tetapi memantaunya cukup baik, sedangkan kemampuan metakognisi yang tidak baik, tidak dapat menjelaskan yang diketahui, tidak memantau setiap langkah yang telah dibuat dan tidak mengevaluasi.

\section{Hasil Analisis Data Kemampuan Metakognisi Siswa Perempuan dalam Memecahkan Masalah Matematis}

Data hasil tes yang diperoleh untuk kemampuan metakognisi pada siswa perempuan: 
Tabel 4: Hasil Tes Kemampuan Metakognisi Siswa dalam Memecahkan Masalah Matematis

\begin{tabular}{c|c}
\hline Ukuran & Siswa Perempuan \\
\hline Rata-rata & 20,97 \\
\hline Skor Tertinggi & 31 \\
\hline Skor Terendah & 5 \\
\hline Standar Deviasi & 6,45 \\
\hline
\end{tabular}

Berdasarkan tabel di atas diperoleh persentase rata-rata bahwa dari 44 orang siswa perempuan dari 78 siswa yang mengikuti tes kemampuan metakognisi siswa perempuan sudah dalam kategori Memuaskan (65,53\%) dari skor ideal.

Berdasarkan hasil kerja siswa dan wawancara diperoleh indikator kemampuan metakognisi:

a. Indikator Perencanaan

Siswa perempuan yang mempunyai kemampuan metakognisi yang baik, pada indikator perencanaan siswa mampu memahami masalah karena dapat mengungkapkannya dengan jelas, siswa tidak mengalami kesulitan dan kebingungan untuk menemukan konsep, dan siswa dapat menjelaskan sebagian besar apa yang ditulisnya, hal tersebut dapat terlihat di lembar jawaban siswa dan juga pada saat wawancara yang peneliti lakukan.

Sejalan dengan hal tersebut, menurut Wilson (Laily Agustina Mahromah, 2013) menyatakan bahwa menyatakan bahwa kesadaran berpikir seseorang dapat diamati, sehingga tingkat kesadaran berpikir siswa dapat diamati pada langkah-langkah yang dilakukannya dalam menyelesaikan suatu masalah.

b. Indikator Pemantauan

Kemampuan metakognisi baik pada siswa perempuan, dapat memberikan alasan kenapa menggunakan rumus, konsep dan strategi untuk menyelesaikan soal yang diberikan. Siswa mengungkapkan alasan siswa menggunakan rumus dan dapat memberikan alasan kenapa siswa menyajikan masalah ke dalam ekspresi matematika terlebih dahulu, hal tersebut dapat dilihat pada saat melakukan wawancara. Saat wawancara, siswa memaparkan bahwa masalah tersebut harus diubah terlebih dahulu menjadi bentuk matematikanya karena panjang dan lebar belum diketahui pada soal. Berdasarkan hal tersebut dapat peneliti paparkan bahwa, siswa yang memiliki cenderung dapat memberikan alasan yang mendukung pemikirannya.

Hal tersebut sejalan dengan hasil penelitian dari Kamid (2013) Subjek perempuan menjawab langsung pertanyaan, peneliti mengajukan pertanyaan pada subjek perempuan yaitu dengan menggunakan rumus, apakah ada kendala dalam melakukan operasi hitungnya?, subjek menjawab dengan menggelengkan kepala sampil terseyum dan menjawab "tidak". Subjek dapat menjawab pertanyaan yang dilontarkan oleh peneliti disini dan terjadi proses metakognisi dimana subjek dapat melaksanakan rencana tindakan dengan memilih strategi penyelesaian masalah matematika karena subjek tidak mengalami kesulitan dan melakukan langkah-langkah dengan mantap.

\section{c. Indikator Penilaian}

Kemampuan metakognisi siswa perempuan pada indikator penilaian yaitunya, siswa melakukan evaluasi. Evaluasi yang dilakukan setelah menyelesaikan masalah tersebut, yaitu siswa memeriksa setiap langkah yang dibuatnya, konsep (rumus) yang siswa gunakan ataupun cara menghitung yang siswa lakukan. Hal tersebut dapat terlihat pada hasil kerja siswa di lembar jawaban dan pada saat wawancara.

Kemampuan metakognisi siswa perempuan melakukan evaluasi terhadap 
apa yang dibuatnya, dimana siswa mengecek kembali terhadap semua langkah yang dibuatnya. Hal tersebut didukung oleh penelitian Kamid (2013) Subjek perempuan dalam mengecek kembali mengungkapkan jawaban dengan menggebu-gebu sambil terus melihat lembar tugas jawabannya dan sangat yakin dengan jawaban yang ia peroleh. Sehingga subjek perempuan dalam mengungkapkan jawaban telah mengevaluasi dan meneliti kembali bagaimana penyelesaian terbaik.

Berdasarkan urutan indikator kemampuan metakognisi siswa mulai dari perencanaan, pemantauan dan penilaian, maka siswa yang memiliki kemampuan metakognisi baik siswa dapat menjelaskan apa yang diketahui dari masalah, menunjukan adanya kesadaran terhadap apa saja yang dipantau, dan melakukan evaluasi.

\section{Analisis Kemampuan Metakognisi Siswa Laki-Laki dan Perempuan dalam Memecahkan Masalah Matematis}

Indikator kemampuan metakognisi siswa dalam memecahkan masalah matematis, meliputi tiga indikator, yaitu perencanaan, pemantauan dan penilaian. Siswa laki-laki dan perempuan yang memiliki kemampuan metakognisi yang baik mampu memahami masalah, merencanakan penyelesaian masalah berdasarkan langkah-langkah memecahkan masalah dan bagaimana saat menguraikan pemikirannya secara tepat, dalam melaksanakan dan memantau langkahlangkah dalam menyelesaikan soal, siswa menjawab setiap langkah masalah matematika merupakan kemampuan siswa dalam melakukan pengecekan kembali terhadap semua langkah yang telah dikerjakan. Kemampuan siswa dalam melakukan pengecekan kembali terhadap semua langkah yang telah dikerjakan.

Siswa dapat memahami masalah dengan baik berdasarkan langkah-langkah memecahkan masalah dan bagaimana saat menguraikan pemikirannya secara tepat. Indikator pemantauan, sisswa laki-laki dan perempuan mampu melaksanakan dan memantau langkah-langkah perhitungan yang telah direncanakan atau merencanakan penyelesaian sesuai dengan rencana yang telah ditetapkan sebelumnya dan mampu menyelesaikan penyelesaian soal masalah matematika dengan cara yang baik dalam menjawab setiap langkah demi langkah pengerjaan dari penyelesaian masalah matematika. Indikator penilaian merupakan kemampuan siswa dalam melakukan pengecekan kembali terhadap semua langkah yang telah dikerjakan. kemampuan siswa dalam melakukan pengecekan kembali terhadap semua langkah yang telah dikerjakan.

Berdasarkan hal di atas terdapat bahwa tidak ada perbedaan kemampuan metakognisi siswa laki-laki dengan siswa perempuan, dapat terlihat bahwa siswa lakilaki dan perempuan memiliki karakter masing-masing untuk menemukan strategi yang tepat untuk memecahkan masalah, serta siswa yang memilih kesadaran pola pikir yang baik maka ia akan mengontrol, merancang, memantau dan menilai apa yang telah dicari sehingga mendapatkan jawabannya yang benar. Hal tersebut sejalan dengan hasil penelitian dari Kamid (2013, p.70-71) menyimpulkan bahwa metakognisi antara siswa laki-laki dan perempuan ketika menyelesaikan soal matematika tidak ditemukan perbedaan. Hal ini dapat dijelaskan pada setiap langkah penyelesaian soal matematika yang mengikuti langkah Polya, memahami, merencanakan, melaksanakan dan melihat kembali hasil pekerjaannya

\section{KESIMPULAN DAN REKOMENDASI}

Kesimpulan penelitian ini adalah kemampuan metakognisi siswa laki-laki dalam memecahkan masalah matematis, terdiri dari tiga indikator, yaitu perencanaan, pemantauan dan penilaian. Siswa laki-laki memikirkan apa yang akan dilaksanakan untuk dapat memahami masalah, memilih strategi/merencanakan penyelesaian masalah dan mampu dalam melaksanakan dan 
memantau langkah-langkah perhitungan yang telah direncanakan atau merencanakan pemyelesaian sesuai dengan rencana yang telah ditetapkan sebelumnya dan mampu dalam melakukan pengecekan kembali terhadap semua langkah yang telah dikerjakan. Kemampuan metakognisi siswa perempuan dalam memecahkan masalah matematis, terdiri dari tiga indikator, yaitu perencanaan, pemantauan dan penilaian. Siswa perempuan memikirkan apa yang akan dilaksanakan untuk dapat memahami masalah, memilih strategi/merencanakan penyelesaian masalah dan mampu dalam melaksanakan dan memantau langkahlangkah perhitungan yang telah direncanakan atau merencanakan pemyelesaian sesuai dengan rencana yang telah ditetapkan sebelumnya dan mampu dalam melakukan pengecekan kembali terhadap semua langkah yang telah dikerjakan. Tidak ada perbedaan kemampuan metakognisi siswa laki-laki dengan siswa perempuan, dapat terlihat bahwa siswa laki-laki dan perempuan memiliki karakter masing-masing untuk menemukan strategi yang tepat untuk memecahkan masalah, serta siswa yang memilih kesadaran pola pikir yang baik maka ia akan mengontrol, merancang, memantau dan menilai apa yang telah dicari sehingga mendapatkan jawabannya yang benar.

\section{DAFTAR KEPUSTAKAAN}

Afriyani, Dona. 2011. Penelusuran Perilaku Metakognitif Mahasiswa Dalam Pemecahan Masalah Matematika

Arikunto, Suharsimi. 2005. Dasar-dasar Evaluasi Pendidikan. Jakarta: Bumi Aksara.

Ilyas, Asnelly. 2006. Evaluasi Pendidikan. Batusangkar: STAIN Batusangkar Press.

In'am, Akhsanul . Peningkatan Kualitas Pembelajaran Melalui Lesson Study Berbasis Metakognisi.

Kamid. 2013. Metakognisi Siswa Dalam Menyelesaikan Soal Matematika (Studi Kasus Pada Siswa Smp Berdasarkan Gender) (online) diakses 4 September 2017.

Mahromah, Laila Agustina. 2013. Identifikasi Tingkat Metakognisi Siswa dalam Memecahkan Masalah Matematika Berdasar Perbedaan skor. Mathedunesa. Vol.2. No. 1.

Sugiyono. 2007. Motode Penelitian Pendidikan. Bandung: Alfabeta

Yamin, Martinis. 2013. Paradigma Baru dalam Pembelajaran. Jakarta: Referensi. 